\title{
Synergistic Actions of Cytokines and Growth Factors in Enhancing Porcine Granulosa Cell Growth
}

\author{
Masatsune FUKUOKA, Keiko YASUDA, Shunzo TAII, And \\ TAKAHIDE MORI \\ Department of Gynecology and Obstetrics, Faculty of Medicine, \\ Kyoto University, Sakyoku, Kyoto 606, Japan
}

\begin{abstract}
In our studies of the growth -promoting effect of a cytokine, interleukin-1 (IL-1), on cultured porcine granulosa cells, we found that the potency of IL-1 action correlated with the serum concentration in the culture medium and that IL-1 acted synergistically with insulin to increase the number of cells in the presence of low serum concentrations $(0.1-1 \%)$. With granulosa cells maintained in a quiescent state under serum-free conditions, we therefore examined the effects of combined treatment with IL-1 and peptide growth factors, including insulin, on $\left[{ }^{3} \mathrm{H}\right]$ thymidine incorporation by these cells. IL- 1 by itself enhanced $\left[{ }^{3} \mathrm{H}\right]$ thymidine incorporation in a concentration-dependent manner. Moreover, IL-1 acted synergistically with insulin, epidermal growth factor (EGF), or fibroblast growth factor (FGF) to enhance $\left[{ }^{3} \mathrm{H}\right]$ thymidine incorporation. Combinations of maximally effective concentrations of insulin $(1 \mu \mathrm{g} / \mathrm{m} l)$, EGF $(1 \mathrm{ng} / \mathrm{ml})$, or FGF $(50 \mathrm{ng} / \mathrm{ml})$ with the maximally effective concentration of IL-1 $(10 \mathrm{ng} / \mathrm{ml})$ increased the levels of $\left[{ }^{3} \mathrm{H}\right]$ thymidine incorporation to $10-, 22-$, and 20 -fold, respectively, over the control values.

Whereas IL-2 $(0.1-100 \mathrm{ng} / \mathrm{m} l)$ did not affect $\left[{ }^{3} \mathrm{H}\right]$ thymidine incorporation, tumor necrosis factor $\alpha$ $(\mathrm{TNF} \alpha)$ stimulated $\left[{ }^{3} \mathrm{H}\right]$ thymidine incorporation by itself and reproduced the actions of IL- 1 to act synergistically with insulin, EGF, or FGF. When IL-1 and TNF $\alpha$ were added together in relatively low concentrations ( $1 \mathrm{ng} / \mathrm{ml}$ each), the combination had synergistic effects in enhancing $\left[{ }^{3} \mathrm{H}\right]$ thymidine incorporation. The present study demonstrates that cytokines and peptide growth factors act synergistically to markedly enhance porcine granulosa cell growth in vitro.
\end{abstract}

Key words: Granulosa cell, Cell growth, Cytokine, Interleukin-1, Tumor necrosis factor $\alpha$.

(Endocrinol Japon 39: 277-288, 1992)

ONE OF THE major features of ovarian follicular development is the proliferation of granulosa cells. Although it is well established that FSH and estradiol stimulate granulosa cell growth in vivo [1-3], these hormones show limited mitogenic potential on granulosa cells in vitro $[4,5]$, suggesting that their effects are mediated by some local factors produced in the ovary. Increasing evidence suggests that some peptide growth factors, includ-

Received: February 3, 1992

Accepted: April 17, 1992

Correspondence to: Dr. Masatsune FUKUOKA, Department of Gynecology and Obstetrics, Faculty of Medicine, Kyoto University, 54 Shogoin Kawaharacho, Sakyoku, Kyoto 606, Japan. ing epidermal growth factor (EGF), fibroblast growth factor (FGF), and insulin and insulin-like growth factors (IGFs), may play roles as such intraovarian regulators of granulosa cell proliferation. These growth factors are mitogenic for granulosa cells in vitro [4-12], and are reported to be present in the ovary or to be produced by ovarian cells [13-15].

We, as well as other workers, have recently shown that cytokines modulate the steroidogenic functions of rat and porcine granulosa cells in vitro (reviewed in Ref. [16]). In a previous paper we also reported that interleukin-1 (IL-1), a cytokine produced predominantly by activated macrophages, stimulated the proliferation of imma- 
ture porcine granulosa cells in culture [17]. However, since these experiments were performed in the presence of a relatively high concentration $(10 \%)$ of serum, we felt that it was possible that IL-1 might have interacted with some factors present in serum to stimulate granulosa cell proliferation. In the present study, therefore, we examined the influence of serum concentrations on the effects of IL-1 on granulosa cell proliferation. In addition, by using a system that can detect the initiation of DNA synthesis in cultures of granulosa cells maintained in a quiescent state under serum-free conditions, we studied the growth-promoting effect of IL-1 as well as that of tumor necrosis factor $\alpha(\mathrm{TNF} \alpha)$, another macrophage-derived cytokine known to influence the steroidogenic functions of cultured granulosa cells [16]. We report here that both IL-1 and TNF $\alpha$ can stimulate growth of porcine granulosa cells and that these cytokines act synergistically with peptide growth factors to markedly enhance granulosa cell growth in vitro.

\section{Materials and Methods}

Cytokines and growth factors

EGF (receptor grade; purified from mouse submaxillary glands) and FGF (purified from bovine pituitary glands) were obtained from Collaborative Research Inc. (Bedford, MA). Bovine insulin was purchased from Sigma Chemical Co., Ltd. (St. Louis. MO). Recombinant human IL- $1 \alpha$ $\left(2 \times 10^{7}\right.$ unit/mg protein $)$ and TNF $\alpha\left(3 \times 10^{6}\right.$ unit/mg protein) were generous gifts from Dainippon Pharmaceutical Co., Ltd. (Osaka, Japan). Recombinant human IL-2 $\left(1 \times 10^{7} \mathrm{unit} / \mathrm{mg}\right.$ protein) was generously provided by Shionogi and Co., Ltd. (Osaka, Japan).

\section{Harvesting of porcine granulosa cells}

Porcine granulosa cells were harvested from small $(1-2 \mathrm{~mm})$ follicles as described previously [17]. The harvested cells were suspended in a culture medium which consisted of Dulbecco's modified Eagle's medium (DME, Nissui Pharmaceutical Co., Ltd., Tokyo, Japan) supplemented with $10 \%$ fetal calf serum (FCS, Grand Island Biological Co., Grand Island, NY) and $100 \mu \mathrm{g} / \mathrm{ml}$ piperacillin sodium (Toyama Chemical Co., Ltd., Tokyo, Japan).

\section{Cell number assay}

The cell number assay was performed as described previously [17]. Porcine granulosa cells were inoculated in $35-\mathrm{mm}$ dishes at a concentration of $4-5 \times 10^{4}$ cells/dish. $24 \mathrm{~h}$ later the medium $(10 \%$ FCS) was removed, and the cells were cultured for 6 more days without or with IL-1 and/or insulin in the presence of various concentrations $(0.1-10 \%)$ of FCS. The cultures received fresh medium containing IL-1 and/or insulin on days 3 and 5 . At the end of the culture (day 7) as well as on day 1 , the number of cell nuclei in the dishes was determined by the citric acid-crystal violet method [18].

\section{$\left.P^{3} H\right]$ Thymidine incorporation by granulosa cells}

The harvested cells were inoculated in tissue culture flasks (Corning Glass Works, Corning, NY) and cultured for 4-7 days with medium changes on alternate days. After the cultures became semiconfluent, the cells were detached from the flasks by incubating them with crystallized trypsin (Mochida Pharmaceutical Co., Tokyo, Japan), as described previously [19]. The reaction was stopped by adding a small volume of medium containing FCS. The viability of the subcultured cells, as assessed by the dye exclusion test using erythrosine $\mathrm{B}$, was always greater than $95 \%$. The cells were resuspended in DME containing 10\% FCS and were inoculated again in 24-well plates (Falcon, Becton Dickinson and Co., Oxnard, CA), at a concentration of $1 \times 10^{5} /$ well. The subcultured cells were incubated at $37^{\circ} \mathrm{C}$ for $24 \mathrm{~h}$ to allow attachment and recovery from the effects of trypsin. The medium was then removed, and the cultures received $0.9 \mathrm{ml}$ of serum-free DME containing $0.2 \%$ BSA (fraction V, Sigma Chemical Co., Ltd., St. Louis, MO) after being rinsed three times with DME that had been preincubated at $37^{\circ} \mathrm{C}$. In order to bring the cells to a "quiescent" state, they were maintained under serum-free conditions for $72 \mathrm{~h}$, unless otherwise stated. After this interval, cytokines and/or growth factors, along with $\left[{ }^{3} \mathrm{H}\right]$ thymidine $\left(\left[\right.\right.$ methyl $\left.-{ }^{3} \mathrm{H}\right]$ thymidine; $37 \mathrm{MBq} / \mathrm{mg}$, Amersham Laboratories, Amersham, England), were added to the appropriate wells. 
Cytokines and growth factors were added in $50 \mu \mathrm{l}$ of PBS containing $0.1 \%$ BSA, and control cultures received the same volume of vehicle. $\left[{ }^{3} \mathrm{H}\right]$ Thymidine was diluted with DME and was added in $50 \mu l$ to give a final concentration of 37 $\mathrm{kBq} / \mathrm{m} l(1 \mu \mathrm{Ci} / \mathrm{m} l)$. The cells were cultured for a further $48 \mathrm{~h}$ in the presence of the cytokines and/or growth factors and $\left[{ }^{3} \mathrm{H}\right]$ thymidine. At the end of the culture period, the medium was removed and the cells were lysed with $0.5 \mathrm{ml}$ of 0.5 $\mathrm{N} \mathrm{NaOH}$, after rinsing twice with PBS. The $\mathrm{NaOH}$ solution was transferred to glass tubes. The plate wells were then rinsed with $0.5 \mathrm{ml}$ of $0.5 \mathrm{~N} \mathrm{HCl}$, and the rinsings were also transferred to glass tubes. Ice-cold trichloroacetic acid, at a final concentration of $10 \%$, was then added to each tube, and the tubes were placed on ice for more than $5 \mathrm{~min}$. The acid-precipitable materials were collected on glass fiber filters, rinsed twice with $5 \%$ TCA and once with ethanol and dried; the radioactivity incorporated was then determined by liquid scintillation counting.

\section{Data analysis}

Data from several experiments were pooled and analyzed by two-way analysis of variance (ANOVA) followed by Tukey's multiple comparison test, unless otherwise stated. Statistical analysis was carried out on a personal computer with a "Yukms Statistical Library I" software package (Yukms Corp., Tokyo, Japan).

\section{Results}

Effects of IL-1, insulin, and their combinations on the number of granulosa cells cultured under various serum concentrations

Using the primary cultures of porcine granulosa cells plated at low density, we first studied whether the concentration of serum in the culture medium might influence the effect of IL-1 on the number of cells. As shown in Table 1, IL-1 significantly increased the number of cultured granulosa cells at every serum concentration tested $(0.1-10 \%)$. However, the potency of IL-1 action correlated positively with the serum concentration, which suggested that some factor(s) present in serum enhanced the growth-promoting effect of IL-1 on
Table 1. Effects of IL-1, insulin, and their combinations on the number of granulosa cells cultured in the presence of serum at various concentrations

\begin{tabular}{|c|c|c|c|c|}
\hline \multirow[b]{2}{*}{$\begin{array}{l}\text { FCS } \\
(\%)\end{array}$} & \multirow[b]{2}{*}{$\begin{array}{l}\text { No. } \\
\text { exp. }\end{array}$} & \multicolumn{3}{|c|}{ Number of cell (\% of control) } \\
\hline & & IL-1 & Insulin & $\begin{array}{l}\text { IL-1 + } \\
\text { Insulin }\end{array}$ \\
\hline 0.1 & 3 & $120 \pm 2^{\mathrm{a}}$ & $121 \pm 8^{a}$ & $189 \pm 11^{\mathrm{d}, \mathrm{e}}$ \\
\hline 1 & 5 & $162 \pm 25^{\mathrm{b}}$ & $154 \pm 19^{b}$ & $323 \pm 46^{\mathrm{d}, \mathrm{e}}$ \\
\hline 5 & 3 & $162 \pm 4^{\mathrm{b}}$ & $N D^{f}$ & ND \\
\hline 10 & 3 & $192 \pm 3^{\mathrm{b}}$ & $112 \pm 4$ & $205 \pm 6^{\mathrm{c}, \mathrm{e}}$ \\
\hline
\end{tabular}

Porcine granulosa cells were cultured for a total of 7 days without or with IL-1 (10 ng/ml) and/or insulin $(1 \mu \mathrm{g} / \mathrm{m} l)$ in the presence of various concentrations $(0.1-10 \%)$ of FCS, as described in "Materials and Methods". The number of cell nuclei in the dishes was counted at the end of the culture. Data are the means \pm SEM for three to five experiments, each performed in triplicate. The number of cells in control dishes cultured in the presence of $0.1 \%, 1 \%, 5 \%$, and $10 \%$ FCS showed 1.1-, 1.9-, 7.0-, and 16.3-fold increases, respectively, over that determined on day 1 . a, $P<0.05$ vs. control; b, $P<0.01$ vs. control; ${ }^{c}, P<0.05$ vs. IL- 1 ; ${ }^{\mathrm{d}}, P<0.01$ vs. IL-1; e, $P<0.01$ vs. insulin; ${ }^{\mathrm{f}}$, Not determined.

granulosa cells. We therefore, next studied whether insulin, a representative of the mitogenic activity in serum, might influence the effect of IL-1 on granulosa cell growth. In the presence of relatively low concentrations $(0.1-1 \%)$ of serum, insulin alone stimulated proliferation of granulosa cells to an extent similar to that observed with IL-1 (Table 1). In the presence of a relatively high concentration $(10 \%)$ of serum, in contrast, insulin did not significantly influence granulosa cell growth. The combination of IL- 1 and insulin acted synergistically to enhance the proliferation of granulosa cells in the presence of low concentrations $(0.1-1 \%)$ of serum. In the presence of $10 \%$ serum, in contrast, insulin had only a minimal influence on the effect of IL-1.

\section{Optimization of conditions for $\left[^{3} H\right]$ thymidine incorpora-} tion

To study the growth-promoting effect of IL-1 on granulosa cells and the effect of combined treatment with IL-1 and insulin in the absence of serum, we have utilized a system that can detect the initiation of DNA synthesis in cultured granu- 
losa cells under serum-free conditions. The experimental protocol involves the subculture and re-establishment of cultures in the presence of serum, followed by a stepdown period to serumfree conditions, followed by a period in which the cells are exposed to cytokines and/or growth factors in the presence of $\left[{ }^{3} \mathrm{H}\right]$ thymidine. The culture conditions in which $\left[{ }^{3} \mathrm{H}\right]$ thymidine incorporation by granulosa cells was to be determined were optimized in several preliminary experiments. The stepdown period was fixed at $72 \mathrm{~h}$, since the basal levels of $\left[{ }^{3} \mathrm{H}\right]$ thymidine incorporation in control cultures reached a minimum after this interval of serum deprivation and were usually less than 3,000 cpm/well. Similarly, the treatment and labeling period was fixed at $48 \mathrm{~h}$, since the levels of $\left[{ }^{3} \mathrm{H}\right]$ thymidine incorporation reached a maximum at $42-48 \mathrm{~h}$ after the addition of the peptides and remained at a plateau until $60 \mathrm{~h}$ at least, regardless of the type of stimulation. In preliminary experiments where pulse labeling was limited to the last $3 \mathrm{~h}$ of treatment with cytokines or growth factors, there was a time lag between the effects of EGF, FGF, and insulin and those of IL-1 and TNF $\alpha$ in inducing a maximal rate of thymidine incorporation (18-24 h vs. 24-30 h, after the initiation of treatment). This protocol was, therefore, not suitable for examining the effects of various combinations of cytokines and growth factors on thymidine incorporation. Since there was no significant difference between the wells in the number of cell nuclei, even after $48 \mathrm{~h}$ of treatment with cytokines or growth factors, the data for $\left[{ }^{3} \mathrm{H}\right]$ thymidine incorporation were not normalized by the number of cells or DNA content.

Effects of IL-1, alone and in combination with insulin, on $\left[^{3} H\right]$ thymidine incorporation

Using the serum-free cultures of subcultured granulosa cells, we first examined the effects of increasing concentrations of IL-1 on $\left[{ }^{3} \mathrm{H}\right]$ thymidine incorporation. As shown in Fig. 1, IL-1 enhanced $\left[{ }^{3} \mathrm{H}\right]$ thymidine incorporation in a concentration-dependent manner. A significant effect was obtained with a concentration of IL- 1 as low as $0.2 \mathrm{ng} / \mathrm{ml}$. The maximal effect was obtained with $10 \mathrm{ng} / \mathrm{m} l$ of IL- 1 , which increased the level of $\left[{ }^{3} \mathrm{H}\right]$ thymidine incorporation to about four times the control value. Next, we examined the influence

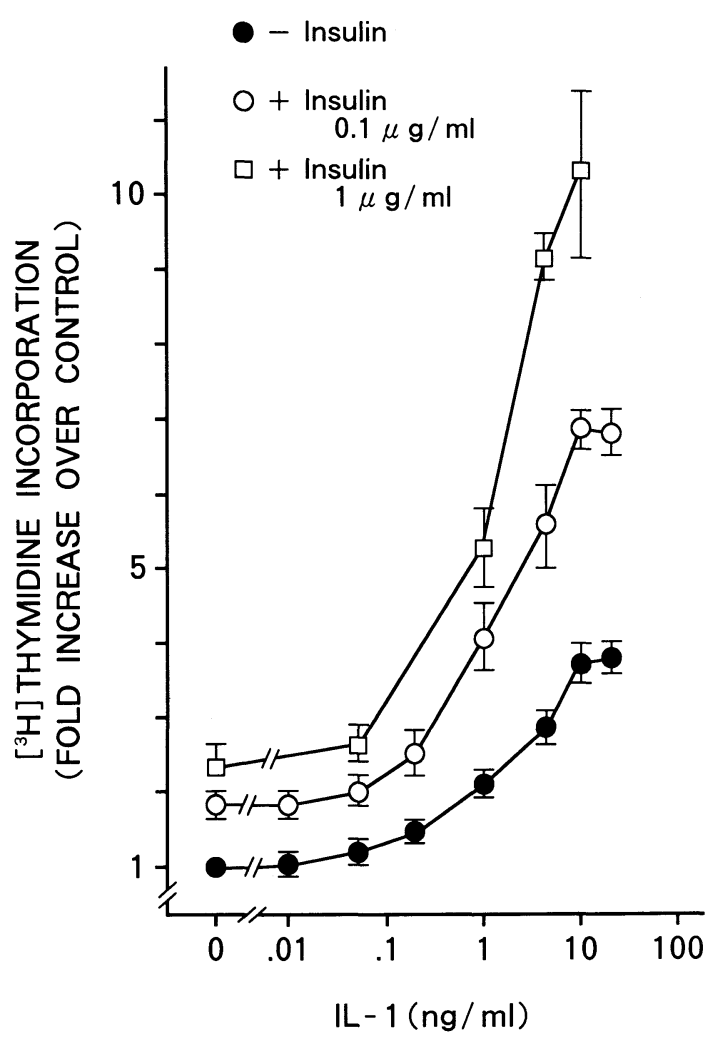

Fig. 1. Effects of IL-1, alone and in combination with insulin, on $\left[{ }^{3} \mathrm{H}\right]$ thymidine incorporation by granulosa cells. Subcultured porcine granulosa cells, after being maintained for $72 \mathrm{~h}$ in serum-free medium, were treated for $48 \mathrm{~h}$ without or with various concentrations of IL-1 $(0.01-50 \mathrm{ng} / \mathrm{m} l)$ and/or insulin $(0.1,1 \mu \mathrm{g} / \mathrm{m} l)$ in the presence of $\left[{ }^{3} \mathrm{H}\right]$ thymidine $(37 \mathrm{kBq} / \mathrm{ml})$. The radioactivity incorporated was determined as described in "Materials and Methods". Data, expressed as fold increases over the values for the control (treated with vehicle only), are the means \pm SEM for three experiments, each performed in triplicate.

of insulin on the facilitative effect of IL-1 on $\left[{ }^{3} \mathrm{H}\right]$ thymidine incorporation. Insulin alone enhanced $\left[{ }^{3} \mathrm{H}\right]$ thymidine incorporation slightly (no more than 2.2-fold), but significantly, at a concentration of $0.1 \mu \mathrm{g} / \mathrm{m} l$ or higher, with the maximal effect being obtained at $1 \mu \mathrm{g} / \mathrm{m} l$. The combination of IL-1 and insulin acted synergistically to enhance $\left[{ }^{3} \mathrm{H}\right]$ thymidine incorporation by granulosa cells. Synergism between IL-1 and insulin was observed with combinations containing IL-1 at concentrations higher than $0.2 \mathrm{ng} / \mathrm{m} l$ and insulin at concentrations of $0.1-1 \mu \mathrm{g} / \mathrm{m} l$. The combination of the maximally effective concentrations of IL-1 (10 $\mathrm{ng} / \mathrm{m} l)$ and insulin $(1 \mu \mathrm{g} / \mathrm{m} l)$ increased the level of 


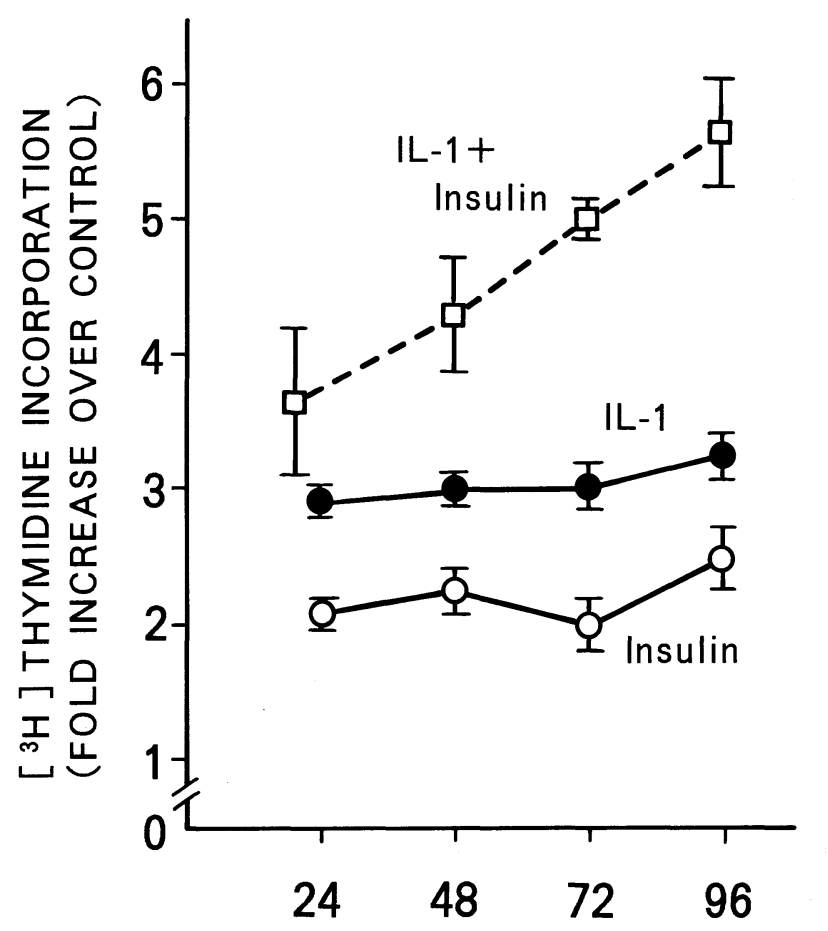

\section{Period of serum deprivation (Hours)}

Fig. 2. Effects of combined treatment with IL-1 and insulin on $\left[{ }^{3} \mathrm{H}\right]$ thymidine incorporation by granulosa cells: Influence of the period of serum deprivation before treatment. Subcultured granulosa cells were maintained in serum-free medium for the period indicated $(24-96 \mathrm{~h})$, after which they were treated for $48 \mathrm{~h}$ without or with IL-1 $(5 \mathrm{ng} / \mathrm{ml})$ and/or insulin $(0.1$ $\mu \mathrm{g} / \mathrm{m} l)$ in the presence of $\left[{ }^{3} \mathrm{H}\right]$ thymidine. The radioactivity incorporated was determined as described in "Materials and Methods". Data, expressed as fold increases over control values, are the means \pm SEM for three experiments, each performed in triplicate.

$\left[{ }^{3} \mathrm{H}\right]$ thymidine incorporation to more than ten times the control value.

Figure 2 shows the influence of the length of the stepdown period on the effects of IL-1, insulin, and their combination on $\left[{ }^{3} \mathrm{H}\right]$ thymidine incorporation. In these experiments, granulosa cells were maintained in serum-free medium for various periods (24-96 $\mathrm{h}$ ) before being treated with IL-1 and/or insulin. When data were expressed in terms of fold increases over control values, as shown in the figure, the effect of either IL-1 or insulin alone on $\left[{ }^{3} \mathrm{H}\right]$ thymidine incorporation was not influenced by the period of serum deprivation before treatment with these factors. In contrast, the effect of concomitant treatment with IL-1 and insulin on $\left[{ }^{3} \mathrm{H}\right]$ thymidine incorporation correlated positively with the period of serum deprivation. The effects of IL-1 and insulin were additive and not synergistic when the stepdown period was $48 \mathrm{~h}$ or less, whereas their effects were synergistic when the period was longer than $48 \mathrm{~h}$, showing that synergy between IL-1 and insulin became more apparent as the influence of serum diminished.

Effects of combined treatment with EGF or FGF and IL-1 on [3H]thymidine incorporation

Seeing that IL-1 acted synergistically with insulin to enhance the initiation of DNA synthesis in granulosa cells cultured under serum-free conditions, we next studied whether IL-1 might also enhance the effects of other growth factors known to stimulate growth of cultured granulosa cells. Figure 3 shows the effects of EGF and FGF, alone or in combination with IL-1, on $\left[{ }^{3} \mathrm{H}\right]$ thymidine incorporation. EGF alone markedly increased the level of $\left[{ }^{3} \mathrm{H}\right]$ thymidine incorporation, which reached about twelve times the control value at its maximally effective concentration $(1 \mathrm{ng} / \mathrm{m} l)$. When a half-maximally effective concentration $\left(\mathrm{ED}_{50}\right)$ of EGF $(0.1 \mathrm{ng} / \mathrm{m} l)$ was given in combination with an $\mathrm{ED}_{50}$ of IL-1 $(1 \mathrm{ng} / \mathrm{ml}),\left[{ }^{3} \mathrm{H}\right]$ thymidine incorporation was synergistically enhanced. With maximally effective concentrations of EGF $(1 \mathrm{ng} / \mathrm{m} l)$ and IL-1 $(10 \mathrm{ng} / \mathrm{ml})$ in combination, there was still a marked synergy in enhancing $\left[{ }^{3} \mathrm{H}\right]$ thymidine incorporation, the level of which reached twenty-two times the control value.

FGF also acted synergistically with IL-1 to enhance $\left[{ }^{3} \mathrm{H}\right]$ thymidine incorporation, as well as enhancing it by itself. The potency of FGF alone in enhancing $\left[{ }^{3} \mathrm{H}\right]$ thymidine incorporation was similar to that observed with IL-1. The combination of maximally effective concentrations of FGF (50 $\mathrm{ng} / \mathrm{m} l)$ and IL-1 $(10 \mathrm{ng} / \mathrm{ml})$ produced a marked synergy in enhancing $\left[{ }^{3} \mathrm{H}\right]$ thymidine incorporation, the level of which reached twenty times the control value. With $\mathrm{ED}_{50} \mathrm{~s}$ of $\mathrm{FGF}(10 \mathrm{ng} / \mathrm{m} l)$ and IL-1 $(1 \mathrm{ng} / \mathrm{m} l)$ in combination, however, this synergistic interaction was less apparent.

EGF and FGF also acted synergistically with insulin. The level of $\left[{ }^{3} \mathrm{H}\right]$ thymidine incorporation obtained with the combination of EGF and FGF, in contrast, was comparable to that obtained with EGF alone. Thus, maximal levels of $\left[{ }^{3} \mathrm{H}\right]$ thymidine incorporation were obtained with combinations of EGF, insulin, and IL-1, whereas the addition of 

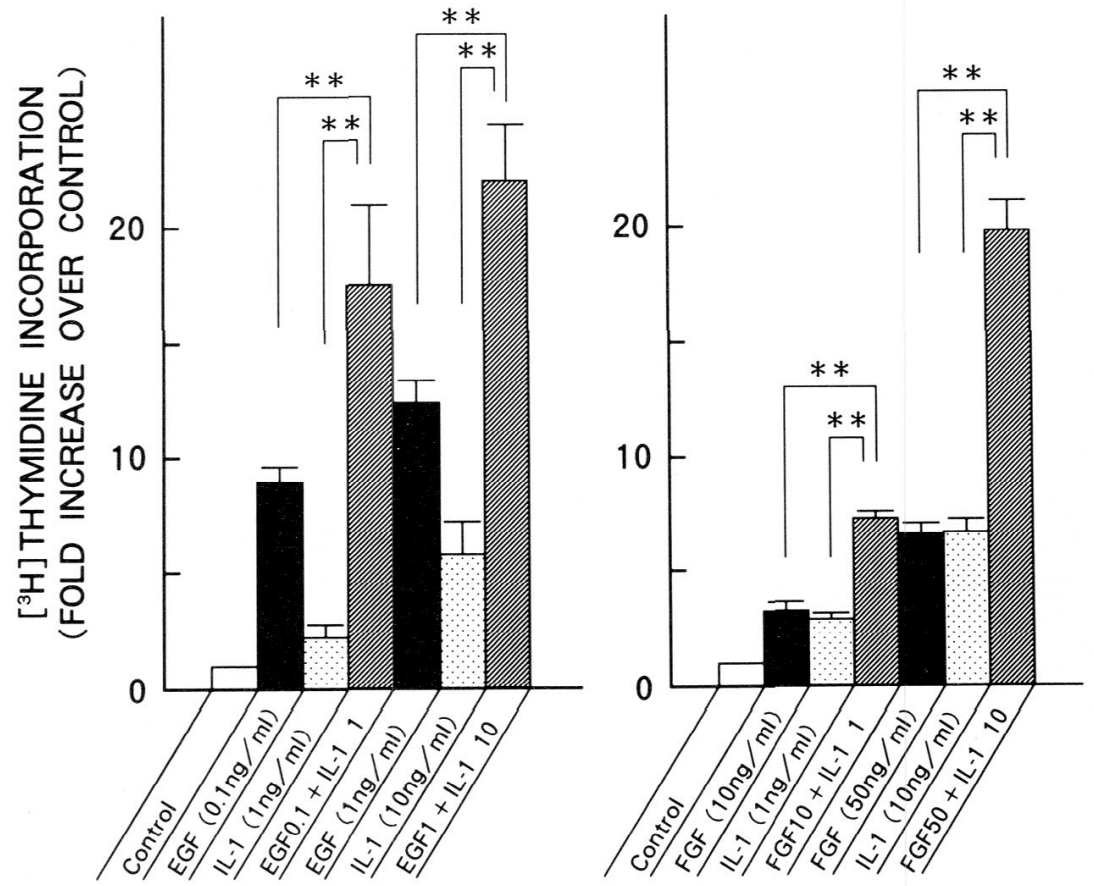

Fig. 3. Effects of combined treatment with EGF or FGF and IL-1 on $\left[{ }^{3} \mathrm{H}\right]$ thymidine incorporation. Granulosa cells, after being maintained for $72 \mathrm{~h}$ in serum-free medium, were treated for $48 \mathrm{~h}$ with either half-maximally or maximally effective concentrations of IL-1 and/or EGF (left panel), or IL-1 and/or FGF (right panel). $\left[{ }^{3} \mathrm{H}\right]$ Thymidine incorporation by granulosa cells was determined as described in "Materials and Methods". Data, expressed as fold increases over control values, are the means \pm SEM for three (EGF) and four (FGF) experiments, respectively. Each experiment was performed in triplicate. ${ }^{* *}, P<0.01$

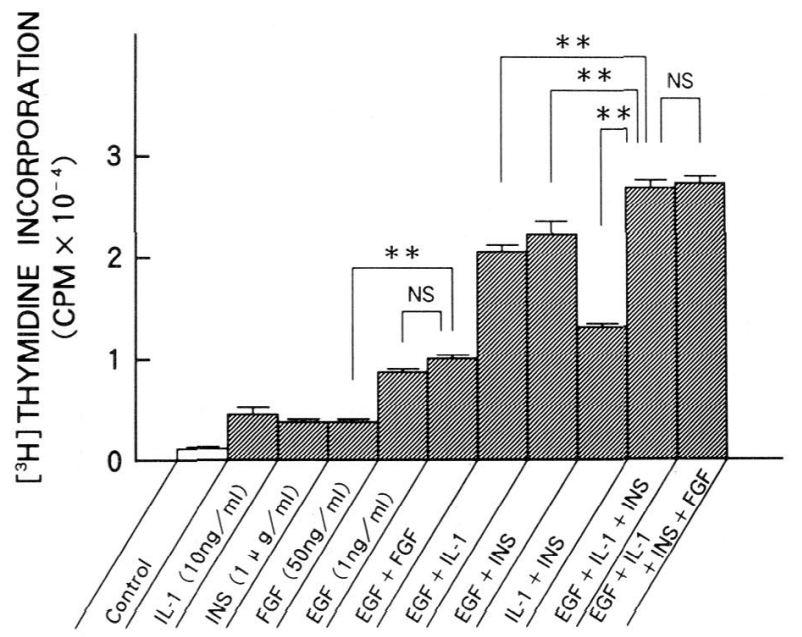

Fig. 4. Effects of various combinations of IL-1, EGF, FGF, and insulin on $\left[{ }^{3} \mathrm{H}\right]$ thymidine incorporation. Granulosa cells, after being maintained for $72 \mathrm{~h}$ in serumfree medium, were treated for $48 \mathrm{~h}$ without or with various combinations of IL-1, EGF, FGF, and insulin Data shown are from a representative experiment and are the mean \pm SEM of triplicate determinations. Similar results were obtained in two other experiments. **, $P<0.01$; NS, not significant, by one-way ANOVA; INS, insulin.
FGF to these three factors did not further enhance $\left[{ }^{3} \mathrm{H}\right]$ thymidine incorporation (Fig. 4).

\section{Effects of TNF $\alpha$ and IL-2 on $\left[^{3} H\right]$ thymidine incorpora-} tion

To study the specificity of IL-1 action, we next examined the effects of two other cytokines, TNF $\alpha$ and IL-2, on $\left[{ }^{3} \mathrm{H}\right]$ thymidine incorporation. As shown in Fig. 5, TNF $\alpha$ increased $\left[{ }^{3} \mathrm{H}\right]$ thymidine incorporation in a concentration-dependent manner similar to that observed in the case of IL-1. The effect of TNF $\alpha$ was significant at a concentration as low as $0.5 \mathrm{ng} / \mathrm{m} l$ and was maximal at 10 $\mathrm{ng} / \mathrm{ml}$, which increased the level of $\left[{ }^{3} \mathrm{H}\right]$ thymidine incorporation to four to five times the control value. In contrast, IL-2, at concentrations of $0.1-100 \mathrm{ng} / \mathrm{m} l$, did not significantly affect $\left[{ }^{3} \mathrm{H}\right]$ thymidine incorporation by granulosa cells. 


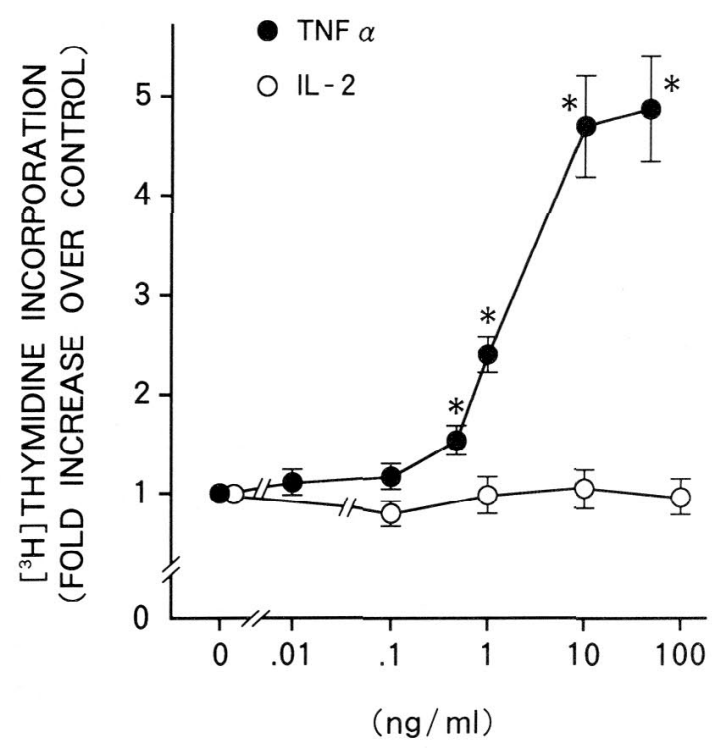

Fig. 5. Effects of TNF $\alpha$ and IL-2 on $\left.{ }^{3} \mathrm{H}\right]$ thymidine incorporation. Granulosa cells, after being maintained for $72 \mathrm{~h}$ in serum-free medium, were treated for $48 \mathrm{~h}$ without or with increasing concentrations of TNF $\alpha$ or IL- 2 . $\left[{ }^{3} \mathrm{H}\right]$ Thymidine incorporation by the cells was determined as described in "Materials and Methods". Data, expressed as fold increases over control values, are the means \pm SEM for three experiments, each performed in triplicate. *, $P<0.05$ vs. control.
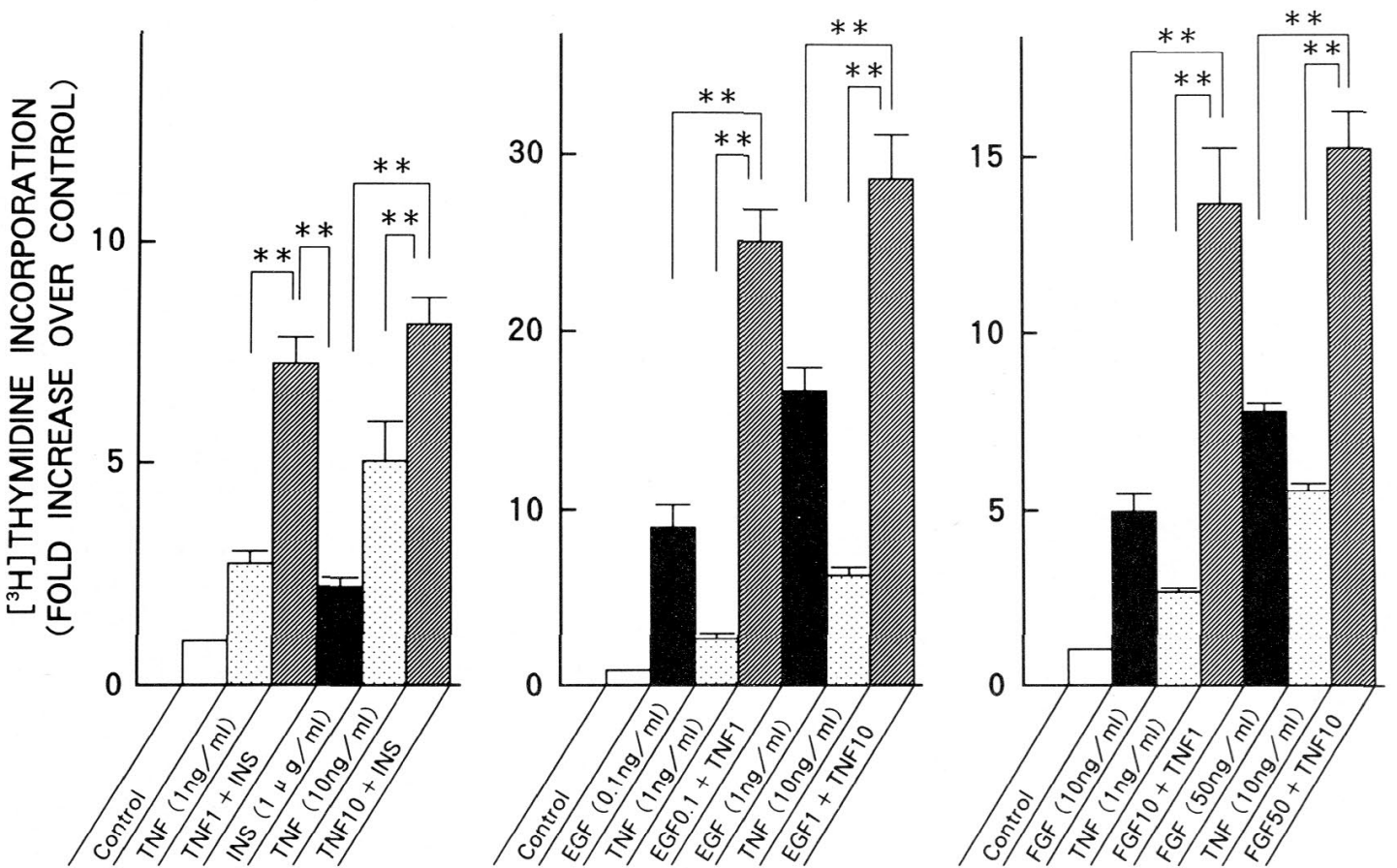

Fig. 6. Effects of combined treatment with insulin, EGF, or FGF and I NF $\alpha$ on $\left.\right|^{3} \mathrm{H}$ |thymidine incorporation. Granulosa cells, after being maintained for $72 \mathrm{~h}$ in a serum-free medium, were treated for $48 \mathrm{~h}$ with either half-maximally or maximally effective concentrations of TNF $\alpha$ and/or insulin (left panel), TNF $\alpha$ and/or EGF (middle panel), or TNF $\alpha$ and/or FGF (right panel). $\left[{ }^{3} \mathrm{H}\right]$ Thymidine incorporation by the cells was determined as described in "Materials and Methods". Data, expressed as fold increases over control values, are the means \pm SEM for four experiments, each performed in triplicate. **, $P<0.01$.

Effects of combined treatment with insulin, EGF, or FGF and $T N F \alpha$ on $\left.{ }^{3} H\right]$ thymidine incorporation

Since TNF $\alpha$ reproduced the effect of IL-1 on $\left[{ }^{3} \mathrm{H}\right]$ thymidine incorporation, we also examined the effects of combined treatment with TNF $\alpha$ and peptide growth factors. As shown in Fig. 6, TNF $\alpha$ acted synergistically with insulin, EGF, and FGF in enhancing $\left[{ }^{3} \mathrm{H}\right]$ thymidine incorporation by granulosa cells. The maximal effective concentration of $\mathrm{TNF} \alpha(10 \mathrm{ng} / \mathrm{m} l)$ in combination with the maximal effective concentrations of insulin $(1 \mu \mathrm{g} / \mathrm{m} l)$, EGF 
Table 2. Effects of the combined treatment with IL-1 and TNF $\alpha$ on $\left[{ }^{3} \mathrm{H}\right]$ thymidine incorporation

\begin{tabular}{lc}
\hline & $\begin{array}{l}{\left[{ }^{3} \mathrm{H}\right] \text { Thymidine }} \\
\text { incorporation }(\mathrm{cpm})\end{array}$ \\
\hline Control & $2,364 \pm 113$ \\
IL-1 $(1 \mathrm{ng} / \mathrm{m} l)$ & $5,468 \pm 760$ \\
TNF $(1 \mathrm{ng} / \mathrm{ml})$ & $5,757 \pm 1,004$ \\
IL-1(1)+ TNF(1) & $16,124 \pm 2,756^{\mathrm{a}, \mathrm{b}}$ \\
IL-1 $(10 \mathrm{ng} / \mathrm{ml})$ & $13,846 \pm 2,238$ \\
TNF $(10 \mathrm{ng} / \mathrm{ml})$ & $9,846 \pm 1,998$ \\
IL-1 $(10)+\mathrm{TNF}(10)$ & $16,200 \pm 2,269^{\mathrm{b}}$ \\
\hline
\end{tabular}

Granulosa cells, after being maintained for $72 \mathrm{~h}$ in a serum-free medium, were treated for $48 \mathrm{~h}$ with either half-maximally ( $1 \mathrm{ng} / \mathrm{ml}$ of each) or maximally (10 $\mathrm{ng} / \mathrm{m}$ l of each) effective concentrations of IL-1 and/or TNF $\alpha .\left[{ }^{3} \mathrm{H}\right]$ Thymidine incorporation by the cells was determined as described in "Materials and Methods". Values are the means \pm SEM for four experiments, each performed in triplicate. a, $P<0.01$ vs. IL-1; b, $P<0.01$ us. TNF $\alpha$.
$(1 \mathrm{ng} / \mathrm{m} l)$, or FGF $(50 \mathrm{ng} / \mathrm{m} l)$ increased the levels of $\left[{ }^{3} \mathrm{H}\right]$ thymidine incorporation to eight times, twenty eight times and fifteen times, the control values, respectively.

\section{Effects of combined treatment with IL-1 and TNF $\alpha$ on $\left[^{3} H\right]$ thymidine incorporation}

We then studied whether the growth-promoting actions of the two macrophage-derived cytokines, IL-1 and TNF $\alpha$, on granulosa cells might be mediated through common pathways. Table 2 shows the effects of IL- 1 and/or TNF $\alpha$ treatment on $\left[{ }^{3} \mathrm{H}\right]$ thymidine incorporation by granulosa cells. Maximally effective concentrations of IL-1 and $\mathrm{TNF} \alpha(10 \mathrm{ng} / \mathrm{m} l$ of each $)$ did not result in an additive effect when added in combination, although the level of $\left[{ }^{3} \mathrm{H}\right]$ thymidine incorporation achieved with the combination of these cytokines was slightly higher than that achieved with either cytokine alone. Concomitant treatment with $\mathrm{ED}_{50} \mathrm{~s}$ of $\mathrm{IL}-1$ and $\mathrm{TNF} \alpha(1 \mathrm{ng} / \mathrm{m} l$ of each $)$, in contrast, synergistically enhanced $\left[{ }^{3} \mathrm{H}\right]$ thymidine incorpora-
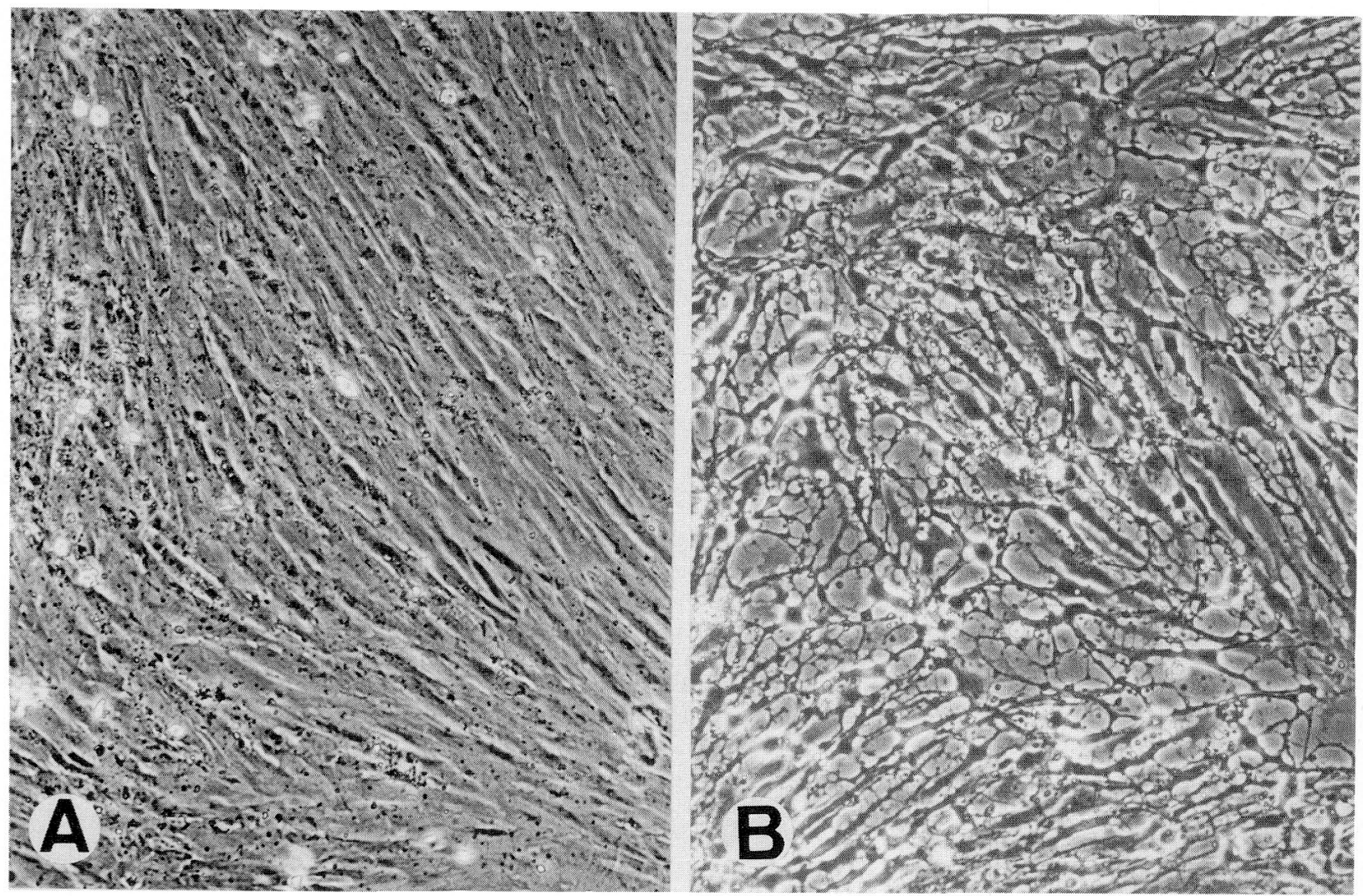

Fig. 7. Morphological changes in granulosa cells in response to cytokines. Granulosa cells, after being maintained for $72 \mathrm{~h}$ in a serum-free medium, were treated without (A) or with $10 \mathrm{ng} / \mathrm{m} l$ of IL-1 (B). Photomicrographs were taken $6 \mathrm{~h}$ after the addition of IL-1 or its vehicle. Magnification, $\times 130$. 
tion to a similar level to that achieved with the combination of maximally effective concentrations of IL-1 and TNF $\alpha$. These results seem to imply that the growth-promoting actions of IL-1 and TNF $\alpha$ on granulosa cells are mediated through common pathways and, moreover, these cytokines can facilitate the actions of each other.

\section{Effects of cytokines on the morphology of cultured granulosa cells}

Observation by means of a phase-contrast microscope revealed that the cultured porcine granulosa cells, both before and after subculture, were flattened and well spread. The cells maintained their flattened morphology in the absence of cytokine treatment (Fig. 7A). In response to stimulation with IL-1 or TNF $\alpha$, in contrast, the quiescent granulosa cells underwent morphological changes, characterized by the shrinking of cytoplasm and the extension of cellular processes, making the cells look like neurocytes (Fig. 7B). These morphological changes were induced by IL- 1 or TNF $\alpha$ at concentrations of $1 \mathrm{ng} / \mathrm{ml}$ or higher. The transformation of the cells began $3 \mathrm{~h}$ after the addition of these cytokines, reached a maximum between 1 and $3 \mathrm{~h}$ later, and lasted for about $10 \mathrm{~h}$, after which the cells regained the flattened morphology. The morphological changes were more pronounced when the cells were treated with IL-1 and TNF $\alpha$ concomitantly than when they were treated with either cytokine alone. In contrast, EGF, FGF, and insulin neither reproduced nor influenced these morphological changes induced by the cytokines.

\section{Discussion}

Increasing evidence suggests the relevance of immunoregulatory factors, generically referred to as cytokines, to the regulation of ovarian cellular function (reviewed in Ref. [16]). Above all, the influence of the two macrophage-derived cytokines, IL- 1 and TNF $\alpha$, on granulosa cell function has been studied extensively. Most of these studies, however, have concentrated on the effects of these cytokines on the steroidogenic functions of granulosa cells. The present study has demonstrated that IL-1 and TNF $\alpha$ enhanced the initiation of DNA synthesis in cultures of porcine granulosa cells maintained in a quiescent state under serumfree conditions. This study also showed that these cytokines synergistically enhanced the actions of the peptide growth factors, EGF, FGF, and insulin. These growth factors have been shown to act solely and/or synergistically to stimulate DNA synthesis and cell proliferation in cultures of porcine and bovine granulosa cells [4-12]. The mechanisms subserving such synergistic actions of cytokines and growth factors are unknown at present. It has been reported by Lorenzo et al. [20] that IL-1 enhanced bone resorption induced by EGF or transforming growth factor- $\alpha$ (TGF $\alpha$ ) in vitro and that these interactions appeared to be dependent on prostaglandin synthesis. Our preliminary data show that prostaglandin $\mathrm{F}_{2 \alpha}$ does not stimulate growth of granulosa cells and that concomitant treatment with indomethacin does not inhibit the facilitative effect of IL-1, suggesting that the growth-promoting effect of IL-1 itself is not mediated by prostaglandins (unpublished observation). However, this does not rule out the possibility that the synergistic effects of IL-1 and growth factors that we observed on granulosa cell growth are mediated by prostaglandins.

Of the peptides examined in the present study, EGF was found to be the most potent mitogen on cultured porcine granulosa cells. Insulin, in contrast, showed limited potential to enhance the initiation of DNA synthesis by itself. Insulin/IGF-I, however, is a well-known "progression" factor in serum [21] and it enhances the actions of other growth factors, including $\operatorname{EGF}[10,11]$. It was shown in the present study that the effect of IL-1 on the proliferation of granulosa cells was enhanced by the presence of serum and that such an action of serum was, at least in part, due to insulin or IGFs. Although EGF and insulin are the potent modulators of granulosa cell growth in vitro, it remains to be elucidated whether they may play physiological roles in vivo. Porcine ovary has been reported to contain an EGF-like activity, which was detected by radioreceptor assay [14]. However, recent studies have suggested that this activity is not that of EGF but of TGF $\alpha$, since the TGF $\alpha$ gene was found to be expressed in theca cells, whereas the EGF gene was expressed neither in theca nor in granulosa cells [22] and, moreover, TGF $\alpha$ interacts with the EGF receptor and its biological activity overlaps that of EGF. Similarly, although IGF-I and insulin both bind to IGF-I receptors 
and stimulate DNA synthesis in granulosa cells to a similar extent, IGF-I seems to be a more plausible candidate for the role of intraovarian regulator of granulosa cell proliferation, since IGF-I is effective at lower physiological concentrations [8].

Multiple overlapping actions of the two monokines, IL-1 and TNF $\alpha$, on immune as well as nonimmune cells have been reported [23]. In several systems, IL- 1 and TNF $\alpha$ have also been shown to act synergistically to regulate cellular function [24-26]. As we have demonstrated in the present study, in cultures of porcine granulosa cells, the actions of IL- 1 and TNF $\alpha$ overlapped, in that both of them enhanced the initiation of DNA synthesis and interacted synergistically with peptide growth factors. The growth-promoting effects of IL-1 and TNF $\alpha$ seemed to be mediated through common pathways. In addition, these cytokines could act synergistically to enhance the initiation of DNA synthesis in granulosa cells. The mechanism of such synergy remains to be elucidated, as is the case in other systems, since the signal transduction pathways of these cytokines are unknown at present. A distant sequence homology exists between FGF and IL-1 [27], which suggests that FGF and IL-1 might show overlapping biological activity. Although these two peptides stimulated the initiation of DNA synthesis in porcine granulosa cells to a similar extent, it appears that the mechanisms of their facilitative actions are different, since their effects were synergistic, even at their maximally effective concentrations. In contrast, the actions of FGF and EGF seemed to be mediated through common pathways.

The morphology of cultured granulosa cells is influenced by several growth factors, especially when the influence of serum is eliminated [10]. This study demonstrated that IL- 1 and TNF $\alpha$ brought about transient but characteristic morphological changes in the quiescent granulosa cells. The morphological changes were observed as an acute effect, beginning as early as $3 \mathrm{~h}$ after the addition of the cytokines and reaching a maximum in $1-3 \mathrm{~h}$, whereas $\left[{ }^{3} \mathrm{H}\right]$ thymidine incorporation in response to the cytokines began 18-24 $\mathrm{h}$ after their addition and reached a maximum at $24-30 \mathrm{~h}$. In addition, such an influence on the cellular morphology was specific to IL-1 and TNF $\alpha$, and was not observed when the cells were stimulated by other growth factors which also enhanced the initiation of DNA synthesis in these cells. It seemed, therefore, that the effect of the cytokines on cellular morphology is independent of their mitogenic action. The acute, characteristic morphological changes induced by IL-1 and TNF $\alpha$ seem to imply direct and specific actions of these cytokines on granulosa cells, although it remains to be elucidated whether the morphological changes may reflect the effect of the cytokines on a specific cellular function.

The present and previous studies show the possible relevance of two macrophage-derived cytokines, IL- 1 and TNF $\alpha$, not only to the differentiation, but also to the growth of granulosa cells. As we have demonstrated in our previous study [17], in the presence of serum, the effect of IL-1 on the proliferation of immature granulosa cells was inversely related with its effect on basal progesterone secretion. Considering that the growth-promoting effects of the cytokines were synergistically enhanced by peptide growth factors and that these growth factors also modulate the steroidogenic functions of granulosa cells [28, 29], there is a possibility that the growth factors might also influence the modulatory actions of the cytokines on the steroidogenic functions of granulosa cells.

Macrophages have been shown to constitute a major cellular component of ovarian interstitial tissue [30]. In addition, it has been reported that relatively high IL-1-like activity was detected in human ovarian follicular fluid [31], and that $\mathrm{TNF} \alpha$ was produced by rat and bovine granulosa cells [32]. These findings support the hypothesis that these cytokines may play permissive roles as autocrine or paracrine regulators of follicular development, although their physiological roles will not be fully understood until the mechanisms regulating their production are clarified. The regulation of granulosa cell growth seems to be a complex process involving multiple factors. Our present study suggests that the interactions between growth factors, between cytokines, and between cytokines and growth factors contribute much to the enhancement of granulosa cell growth.

\section{Acknowledgments}

We thank Dainippon Pharmaceutical Co., Ltd. for generously providing us with recombinant 
human IL- $1 \alpha$ and TNF $\alpha$, and Shionogi and Co.,

IL-2.

Ltd. for their generous gift of recombinant human

\section{References}

1. Goldenberg RL, Vaitukaitis JL, Ross GT (1972) Estrogen and follicle-stimulating hormone interactions on follicle growth in rats. Endocrinology 90 : 1492-1498.

2. Richards JS (1979) Hormonal control of ovarian follicular development: a 1978 perspective. Recent Prog Horm Res 35: 343-373.

3. Rao MC, Midgley AR Jr, Richards JS (1978) Hormonal regulation of ovarian cellular proliferation. Cell 14: 71-78.

4. Savion N, Lui GM, Laherty R, Gospodarowicz D (1981) Factors controlling proliferation and progesterone production by bovine granulosa cells in serum-free medium. Endocrinology 109: 409-420.

5. Hammond JM, English HF (1987) Regulation of deoxyribonucleic acid synthesis in cultured porcine granulosa cells by growth factors and hormones. Endocrinology 120: 1039-1046.

6. Gospodarowicz D, Ill CR, Birdwell CR (1977) Effects of fibroblast and epidermal growth factors on ovarian cell proliferation in vitro. I. Characterization of the response of granulosa cells to FGF and EGF. Endocrinology 100: 1108-1120.

7. Gospodarowicz D, Bialecki H (1979) Fibroblast and epidermal growth factors are mitogenic agents for cultured granulosa cells of rodent, porcine, and human origin. Endocrinology 104: 757-764.

8. Baranao JLS, Hammond JM (1984) Comparative effects of insulin and insulin-like growth factors on DNA synthesis and differentiation of porcine granulosa cells. Biochem Biophys Res Commun 124: 484-490.

9. Adashi EY, Resnick CE, D'Ercole AJ, Svoboda ME, Van Wyk JJ (1985) Insulin-like growth factors as intraovarian regulators of granulosa cell growth and function. Endocr Rev 6: 400-420.

10. May JV, Frost JP, Schomberg DW (1988) Differential effects of epidermal growth factor, somatomedin-C/insulin-like growth factor I, and transforming growth factor- $\beta$ on porcine granulosa cell deoxyribonucleic acid synthesis and cell proliferation. Endocrinology 123: 168-179.

11. Keel BA, Eddy KB, Cho S, May JV (1991) Synergistic action of purified $\alpha$-fetoprotein and growth factors on the proliferation of porcine granulosa cells in monolayer culture. Endocrinology 129: 217-225.

12. Bendell JJ, Dorrington JH (1990) Epidermal growth factor influences growth and differentiation of rat granulosa cells. Endocrinology 127:
533-540.

13. Hammond JM, Baranao JLS, Skaleris D, Knight AB, Romanus JA, Rechler MM (1985) Production of insulin-like growth factors by ovarian granulosa cells. Endocrinology 117: 2553-2555.

14. Hsu CJ, Holmes SD, Hammond JM (1987) Ovarian epidermal growth factor-like activity. Concentrations in porcine follicular fluid during follicular enlargement. Biochem Biophys Res Commun 147: 242-247.

15. Neufeld G, Ferrara N, Schweigerer L, Mitchell R, Gospodarowicz D (1987) Bovine granulosa cells produce basic fibroblast growth factor. Endocrinology 121: 597-603.

16. Adashi EY (1990) The potential relevance of cytokines to ovarian physiology: The emerging role of resident ovarian cells of the white blood cell series. Endocr Rev 11: 454-464.

17. Fukuoka M, Yasuda K, Taii S, Takakura K, Mori T (1989) Interleukin-1 stimulates growth and inhibits progesterone secretion in cultures of porcine granulosa cells. Endocrinology 124: 884-890.

18. Patterson Jr MK (1979) Measurement of growth and viability of cells in culture. In: Jacoby WB, Pastan IH (eds) Methods in Enzymology. Academic Press, New York, vol 58: 141-152.

19. Fukuoka M, Mori T, Taii S, Yasuda K (1988) Interleukin-1 inhibits luteinization of porcine granulosa cells in culture. Endocrinology 122: 367-369.

20. Lorenzo JA, Sousa SL, Centrella M (1988) Interleukin-1 in combination with transforming growth factor- $\alpha$ produces enhanced bone resorption in vitro. Endocrinology 123: 2194-2200.

21. Stiles CD, Capone GT, Scher CD, Antoniades HN, Van Wyk JJ, Pledger WJ (1979) Dual control of cell growth by somatomedins and platelet-derived growth factor. Proc Natl Acad Sci USA 76: 1279-1283.

22. Skinner MK, Coffey RJ Jr (1988) Regulation of ovarian cell growth through the local production of transforming growth factor- $\alpha$ by theca cells. Endocrinology 123: 2632-2638.

23. Le J, Vilcek J (1987) Tumor necrosis factor and interleukin 1: cytokines with multiple overlapping activities. Lab Invest 56: 234-248.

24. Stashenko P, Dewhirst FE, Peros WJ, Kent RL, Ago JM (1987) Synergistic interactions between interleukin 1, tumor necrosis factor, and lymphotoxin in bone resorption. J Immunol 138: 1464-1468. 
25. Last-Barney K, Homon CA, Faanes RB, Merluzzi VJ (1988) Synergistic and overlapping activities of tumor necrosis factor- $\alpha$ and IL-1. I Immunol 141: $527-530$.

26. Sato K, Satoh T, Shizume K, Ozawa M, Han DC, Imamura $\mathrm{H}$, Tsushima $\mathrm{T}$, Demura $\mathrm{H}$, Kanaji $\mathrm{Y}$, Ito Y, Obara T, Fujimoto Y, Kanaji Y (1990) Inhibition of ${ }^{125} \mathrm{I}$ organification and thyroid hormone release by interleukin-1, tumor necrosis factor- $\alpha$, and interferon- $\gamma$ in human thyrocytes in suspension culture. J Clin Endocrinol Metab 70: 1735-1743.

27. Gimenez-Gallego G, Rodkey J, Bennet C, Rios Candelore M, Disalvo J, Thomas K (1985) Brainderived acidic fibroblast growth factor: Complete amino acid sequence and homologies. Science 230: 1385-1388.

28. Tsafriri A (1988) Local nonsteroidal regulators of ovarian function. In: Knobil E, Neil JD (eds) The Physiology of Reproduction. Raven Press, New York, vol 1: 527-565.

29. Hsueh AJW, Bicsak TA, Jia X, Dahl KD, Fauser
BCJM, Galway AB, Czekala N, Pavlou SN, Papkoff H, Keene J, Boime I (1989) Granulosa cells as hormone targets: The role of biologically active follicle-stimulating hormone in reproduction. $R e$ cent Prog Horm Res 45: 209-277.

30. Hume DA, Halpin D, Charlton H, Gordon S (1984) The mononuclear phagocyte system of the mouse defined by immunohistochemical localization of antigen F4/80: macrophages of endocrine organs. Proc Natl Acad Sci USA 81: 4174-4177.

31. Khan SA, Schmidt K, Hallin P, Di Pauli R, De Geyter C, Nieschlag E (1988) Human testis cytosol and ovarian follicular fluid contain high amounts of interleukin-1-like factor(s). Mol Cell Endocrinol 58: 221-230.

32. Roby KF, Terranova PF (1989) Localization of tumor necrosis factor (TNF) in the rat and bovine ovary using immunocytochemistry and cell blot: evidence for granulosal production. In: Hirshfield AN (ed) Growth Factors and the Ovary. Plenum Press, New York, 273-278. 